International Journal of English Literature and Social Sciences
Vol-6, Issue-3; May-Jun, 2021

\title{
The Lonely Victims of the Glass Menagerie
}

Peer-Reviewed Journal

\author{
K. Kamalaveni ${ }^{1}$, Dr. R. Venkataraman ${ }^{2}$ \\ ${ }^{1} \mathrm{Ph} . \mathrm{D}$ Scholar, English Dept, SCSVMV University, Kanchipuram, Tamil Nadu, India \\ ${ }^{2}$ Prof \& HoD, Vels University, Chennai, Tamil Nadu, India
}

Received: 07 Mar 2021; Received in revised form: 03 May 2021; Accepted: 15 May 2021; Available online: 27 May 2021

C2021 The Author(s). Published by Infogain Publication. This is an open access article under the CC BY license

(https://creativecommons.org/licenses/by/4.0/).

\begin{abstract}
Loneliness is a part of the human condition. It is not synonymous with being alone because one can be alone and not feel lonely. It can drive people into all kinds of social and mental problems, often making life almost unbearable for themselves and for those around them. People experience it subjectively when certain needs are deprived. There are many possible sources of loneliness, both situational, circumstantial and personal or psychological. There is bitterness in the feeling of loneliness. Generally people take refuge in isolation, in an attempt to escape from the world of reality. Lonely women experience a kind of death-in-life and also a feeling of anxiety, emptiness, shyness and boredom. Nearly breaking them psychologically. Tennessee Williams attempts to depict the problems of lonely broken women in his plays. His dramas can be read as an obsession with loneliness and enduring dread of inevitably failed communication.
\end{abstract}

Keywords—synonymous, subjectively, circumstantial, refuge, obsession.

\section{INTRODUCTION}

Theme of Loneliness and longing for acceptance is a common theme in most of William's plays. His characters try to resort to illusion to escape from the stark realities of life and loneliness. His writings were successful primarily because he was able to give a true picture of the pathos and plight of the family life in a very realistic manner. In Williams plays, the attention is centered primarily upon the inner life of the characters. The difficulties of each character of his plays are more of a psychological nature rather than social or political. Williams talks a great deal about decayed southern aristocracy and in most of his plays there is a similarity with regard to the plight of women. Most of his women characters exhibit the psychological trauma faced in life and their futile attempts to escape from reality by taking refuge in isolation.

Loneliness is a part of the human condition which is a universal problem. It is not synonymous with being alone because one can be alone and not feel lonely. It can drive people into all kinds of social and mental problems, often making life almost unbearable for themselves and for those around them. People experience it subjectively when certain needs are deprived. The basic need of those whose frustration leads to loneliness is the maintenance of linkage with one's own world. There is a bitterness in the feeling of loneliness. Generally people take refuge in isolation, in an attempt to escape from the world of reality. Thus lonely women can experience a kind of death-in-life and also a feeling of anxiety, emptiness, shyness and boredom. They are compelled to follow a routine consisting of meaningless activity.

\section{DISCUSSION}

'Tennessee Williams' "The Glass Menagerie" (1945) established him as an important play-wright in the canon of American plays. It represents a vision of lonely human beings who fail to make contact with reality and struggle to encounter it. They find release in a world of willful illusions and isolation. They seem ultimately abandoned in this universe.

The Glass Menagerie, William's first play, portrays Amanda as a widow, taking refuge in the past glory, who considers herself as a member of the decayed Southern aristocracy reveling in her illusive dreams. Both Amanda and Laura are interpreted as the lovely Southern 
women whose household lacks the support of men through desertion. Amanda is denied the social acceptance. She had been a popular and charming belle and is forced into obscure existence. While she attempts to escape into the past, her crippled daughter Laura seeks refuge in her glass collection.

Amanda was married to Mr. Wingfield. He was working in a telephone company. Though she admired and loved him, her marital life was not blissful. He deliberately abandoned the family and Amanda had to face all the hardships and bring up her two children. Anybody in her place would certainly feel deeply hurt. She had several gentleman callers but she was drawn towards $\mathrm{Mr}$. Wingfield. But her marriage with him was a total failure. A blown up photograph of the father is placed on the wall of the living room. He is not physically present to run the family. It is indeed Amanda who takes the responsibility of running the family, thereby endowing masculine practicality. It is her practicality that gives her dignity in spite of her loneliness

Amanda is forced to live in dreary lower middle class surroundings. Tom's income which is meager is hardly enough to maintain the family. So she sells magazine subscriptions to make a little more money. Oneof the reasons for her loneliness is that she does not understand her children although she loves them and strives for their wellbeing. A dominating mother, she expects total submission. She does not have proper contact with Tom. Both of them quarrel frequently. She is disgusted with Tom because he has not molded his taste as per her wish. She does not want him to even violate the eating habits. She wants him to chew his food leisurely and enjoy it. But Tom is irritated with his mother when she interferes even while he is eating. Tom wants to be a creative writer but Amanda wants him to "Rise and Shine" every morning to work in the office of the continental shoemakers.

Amanda is disturbed and feels lonely because Tom is not what she wants him to be. She is desperate to see that Laura is married to someone who would take care of her she knows that Lara is yet to be provided with a secure life. She wants Tom to help Laura to be married to a decent man who would take care of her life long. She does not want her to experience the sense of loneliness due to lack of security.

Amanda tries to escape from the clutches of loneliness by recollecting the past. In the opening scene, she is found recalling her past life of happiness as a young Southern belle in Blue Mountain where, on one Sunday she had seventeen gentleman callers. She is distressed because the life led in the South is no more. She feels lonely whenever she realizes that the reality is harsh unlike the past. So she likes to retreat into the comfort of memory to escape from the clutches of loneliness.

She fails to realize that she expects too much from her children. Amanda's constant nagging and her endless retelling of romantic stories of her childhood stifles Laura and Tom. She feels isolated because she knows that her children are not impressed with her behavior. Amanda represents the desperate American woman during the depression era, longing for acceptance by her loved ones. She blindly follows the routine pattern of domestic life and fights all alone for a decent existence without any support from her loved ones. She under goes stressful situations and her life is pregnant with anxieties. Fighting with lot of valor and endurance she appears to have accepted her present fate.

It is true that Laura is lonelier than Amanda. She is the most pitiable of the three members of the family. It is a fact that she suffers from a painful sense of loneliness, for, from the first scene to the last, popularity with men and her inability to cope with any kind of social life is evident. Laura's slight limp is the cause of her shyness. She is unable to sustain the pressures of the outside world and often takes refuge in old gramophone records and in tending her collection of glass animals. She is intensely attached to her glass animals. When Tom throws his coat and accidentally knocks some off the shelf she cries out as if wounded and covers her face with her hands.

Laura's failure at Rubicam's Business College is also due to her nervousness. She likes to remain lonely, for, she finds ordinary human relationship almost unbearable. Through her timidity, her suffering from the clashes between Tom and Amanda, this delicate sufferer evokes genuine sympathy. She stands as a buffer between the mother and son. Amanda herself knows that Laura broods about Tom who is not happy in the apartment. Laura is a loner who lacks peace of mind.

Her encounter with Jim O' Connor intensifies her sense of loneliness. Laura's dream of possible relationship with Jim is shattered by the unexpected revelation of his forthcoming marriage with another woman. She now realizes that she belongs to a different world from Jim and that it is difficult for her to lead a normal life like others. After giving Jim the broken unicorn, a symbol of her own condition, as a sovereign, she withdraws into a world of silence. She recedes' into the broken world of music and glass figures. Briefly she is drawn out of her private world only to be brutally thrust back into it again. Her loneliness, never to be altered.

Laura's glass animals represent delicacy, beauty and a peaceful atmosphere. It symbolizes Laura's fragile 
world, her delicacy, her beauty, and her unworldliness and fragility. Amanda's illusion of Laura's marriage is shattered when Jim reveals that he is already engaged to marry someone else. Now Laura and Amanda share a common experience of loss. Amanda realizes the complete destruction of her family. She accepts that her attempts to find a husband for Laura and efforts to prevent Tom form abandoning home are a failure. At the end of the play we find that Amanda and Laura are broken, fragment people because they are unable to cope up with reality and live in a world of frustration and isolation.

One prominent factor for the loneliness felt by the characters of The Glass Menagerie is the theme of 'loss'. The very fact that the play is a memory play and is a recollection of a part of life of Tom which he is unable to come to terms with, sets the stage for the 'loss' which serves as the driving source of the play. The Glass Menagerie is a play of the universal truth - which is a condition where an individual is unable to escape a psychological loss of space whatever be the physical distance that is obtained.

Both Amanda and Laura are pathetic victims in The Glass Menagerie perhaps the saddest victim in the play is Laura, a fragile and delicate creature like her glass collection of animals. She turns her back to reality and is both alienated and isolated from the outside world. Always a loner she is petrified to attend business school and nervous and frightened when her mother and brother argue. She cannot mingle with people and involves herself in solo activities like visiting the zoo, listening to records or attending to her collection of glass animals. Prisoner of her physical ailment she feels secure only in her loneliness

\section{CONCLUSION}

In the characterization of women, the supremacy of Williams' art is recognized by almost every reader. All types of women like married, unmarried, widowed and fallen ones and the general problems of these women are reflected in his plays. They suffer chiefly from loneliness. They are all deprived of human connection. Williams portrays their desperate attempt to communicate with each other. Williams' protagonists in almost every play face devastating loneliness. They sing the same old refrain "nobody knows how lonesome I am" a song dove-tailed by appropriate off stage moods like mournful locomotive whistles or bird calls.

The basic requirement for the lonely women like Amanda and Laura is love. Love starved women destabilize themselves and their surroundings. To escape from the harsh reality they take refuge into an illusory world. They are ready to grasp any hand that is stretched out to them and get rescued. It is the duty of every man to feed the women of his world with love, warmth and security.

\section{REFERENCES}

[1] Williams Tennessee, The Glass Menagerie (New york: New Directions publishing corporation, 1945).

[2] Falk Signi Lenea, Tennessee Williams (New York: Twayne publishes, 1978)

[3] Dusenbury Winifred, The theme of loneliness in Modern American Drama. (Gainsville: University Florida press, 1960)

[4] Tischler Nancy, Tennessee Williams: The Rebellious Puritan (New York: citadel press, 1961) 